Cal International Journal of Industrial and Business Management (ISSN:2572-8423)

\title{
Service Quality in the Eritrean Banking Sector
}

\section{Fitsum Ghebregiorgis ${ }^{1}$ and Asmerom Atewebrhan ${ }^{2}$}

${ }^{1}$ Department of Business Management and Marketing, College of Business and Economics, P.O. Box 3963 Asmara, Eritrea; ${ }^{2}$ Department of Accounting, College of Business and Economics, P.O. Box 3963 Asmara, Eritrea

\section{ABSTRACT}

This paper aims at measuring the quality standing of the banking sector in Eritrea. It focuses on the study of the Eritrean Commercial Banks in order to examine their performance towards quality service and behavioural intentions. The findings from the study reveal mixed evidence in that, although customers' base their banks' overall quality assessment on the service quality dimensions identified in this study, they do not consider the service quality dimensions identified to be important in their intention to spread positive word-of-mouth about their bank's services and they seem to be willing to switch to another bank even with a positive perception of service quality. Thus, there may be considerations other than the quality dimensions identified in this study on which customers base their future purchase which seeks further study. In comparison with similar service quality studies made in other countries, this study has comeup with new dimensions. Hence, the outcome may enrich our understanding of services marketing and the determinant variables in what customer perceive regarding quality service in a developing country setting. Future research would benefit from additional research in this area in other geographical settings to better understand the generalisability of the findings reported.

\section{Keywords:}

*Correspondence to Author:

Fitsum Ghebregiorgis

Department of Business Management and Marketing, College of Business and Economics, P.O. Box 3963 Asmara, Eritrea; Tel: + 2917161013; e-mail: fitadiam @ gmail. com

How to cite this article:

Fitsum Ghebregiorgis and Asmerom Atewebrhan. SERVICE QUALITY IN THE ERITREAN BANKING SECTOR. International Journal of Industrial and Business Management, 2017; 1:5.

\section{eSciencePublisher $\partial$}

eSciPub LLC, Houston, TX USA. Website: http://escipub.com/

Service quality, banking sector, customers, behavioural intentions, Trade, Eritrea. 


\section{INTRODUCTION}

Consumers make buying decisions and cling to product brands due to perceptions of quality. Consequently, it is one of the important reasons why customers engage in a relationship with a service provider. As a result service firms have been repeatedly cautioned about the importance of quality to their customers (Boshoff et al. 1994, Zeithaml et al. 1996). Studies have reported that quality has apparent relationship with many facets of competitive advantage such as costs, profitability, customer satisfaction and retention, market share, and return on investment (Sachdev and Verma 2002; Zeithaml, et al. 1996; Richard and Allaway 1993). Accordingly service businesses have used quality in order to gain these advantages.

Unlike goods, service quality is not engineered at the manufacturing plant, then delivered intact to the consumer. Service quality cannot be assured by counting, measuring, testing, and verifying in advance of the sale. Furthermore, in services with high labour content (such as banks), quality occurs during service delivery, usually in an interaction between the customer and the contact personnel of the service firm. This causes the performance of services to often differ among employees, among customers, and from day to day. As a result, 'service quality is highly dependent on the performance of employees, an organisational resource that cannot be controlled to the degree that components of tangible goods can be engineered' (Zeithaml et al. 1988: 35). Thus, in the measurement of service quality, one has to recognise that assessment is made not only on service outcome, but also on the process of service delivery. The concerns discussed hitherto also apply to the banking industry because, banking service, like other services, is intangible and, therefore, difficult to measure.

At present, Eritrean banking sector is dominated by two major banks, namely Commercial Bank of Eritrea (CBER) and Housing and Commerce Bank of Eritrea (HCBE). After independence in 1991, the Eritrean banking sector inherited an obsolete monetary and financial system from the Ethiopian Marxist government. Between 1974 and 1991 the military government of Ethiopia nationalized the banking sector and converted it into an appendage of the state administration. In this system, bankers were transferred into civil servants and bureaucrats, devoid of any sense of customer needs and expectations (Tsegai, 1999). It is this type of archaic organizational structure and banking behaviour that the Eritrean banking system is trying to leave behind. Currently, the Eritrean banking sector can be characterized as small, state-owned, undeveloped and providing rudimentary banking and other financial services to the economy (Ibid. 1999).

This study aims at measuring the quality standing of the banking sector in Eritrea. Hence, we have focused our study on the Eritrean Commercial Banks in order to examine their performance towards quality service. We have also investigated the impact of service quality perception on the behavioural intentions of the customers of these banks.

\section{EMPRICAL LITERATURE HYPOTHESES}

An understanding of the characteristics of the service sector is necessary in the selection of an appropriate instrument to measure service quality. Such an instrument needs to accommodate the difficulties and peculiarities raised in the previous sections. Service output is characterised inter alia by high involvement of the consumer, which leads him/her to a greater noticing of the process (Lehtinen and Lehtinen 1991; Grónroos 1984). This implies that, in the service industry, quality measurement seems to be in terms of the result of the comparison that customers make between their expectations and perceptions about the service (Caruna et al.1998; Zeithaml et al. 1988; Grónroos 1984; Parasuraman et al.1985). Therefore, the client's perceptions is more important than that of the service provider's in determining service quality, although a comparison can be made between the perceptions of the two sides (Mongos et al. 1995).

Although Grónroos's conceptualisation of service quality was the first to be aired in the academic literature, it has been the work of Parasuraman et al. $(1985,1988,1991 a)$ in developing and promulgating a technology for measuring and managing service quality [SERVQUAL model] which has received the most attention (Grapentine 1998). Since then, a number of studies have tried to operationalise 
theoretical frameworks and introduce various methodologies for the measurement of service quality in various service sectors (e.g. Cronin and Taylor 1992; Bolton and Drew 1991).

The SERVQUAL model is the most popular service quality measurement instrument that has been extensively applied for various services (e.g. Sachdev and Verma 2002; Urdang and Howey 2001; Nel et al. 1997; Dassen 1995; Richard and Allaway 1993). However, several researchers have recognised that both the instrument itself and the conceptualisation of service quality may benefit from further refinement (Nagata et al. 2004; Woo and Ennew, 2005; Buttle 1996; Richard and Allaway 1993; Cronin and Taylor 1992; Babakus and Boller 1992).

Cronin and Taylor (1992) conducted a study in four service industries to investigate whether a performance-only instrument of service quality measurement is superior to the expectationperformance gap model. On the basis of this study, they contend that in all industries surveyed, the performance-only instrument (which they called SERVPERF) explains more of the variations in the global (overall) measure of service quality. Thus, the authors concluded that the gap model's expectation component is unnecessary, although this conclusion has been challenged by Parasuraman et al. (1994a) in an article they wrote in response to Cronin and Taylor and Teas (another critic of the model).

In this study, we have employed the performanceonly model (SERVPERF) which is based on customers' perception of service providers' performance as suggested by Cronin and Taylor (1992). The model has received significant conceptual and empirical support in services research (Zhou 2004).

Different studies have tried to identify dimensions of service quality and measure to what extent these dimensions define the concept (see Reeves and Bednar 1994; Boshoff et al. 1994; Gronroos 1990; Zeithaml et al. 1990). In that line, we also have identified attributes of bank service quality that will reflect the different dimensions of the construct. During the process the service provider almost continuously interacts with the client. This interaction, obviously, affects the client's assessment of how well the service was provided in both favourable and unfavourable directions. Theoretical and empirical studies (Nagata et al. 2004; Sweeney, et al. 1997; Dassen 1995; Lehtinen and Lehtinen 1991; Parasuraman et al. 1988 and 1985; Grónroos 1984) have argued that there is a positive relationship between service quality attributes and the overall assessment of service quality. In the banking sector (Aldlaigain and Buttle 2002; Karatepe et al. 2005) found that the bank quality dimensions they identified are highly correlated with overall service quality. Therefore, we hypothesise that:

H1 All bank service quality dimensions identified in this study will have a positive influence on customers' perceived overall bank service quality.

Researchers on service marketing and many enlightened business managers have realized that providing a quality service is a strategic tool influencing market share at the aggregate level and future purchase intentions at the individual level (Richard and Allaway 1993). One of the objectives of this study is to understand the impact of bank service quality factors on customers' behavioural intentions. The decision of customers on whether or not to continue to do business with the company is termed in the marketing literature as customers' behavioural intentions and is defined as the customer's intentions to repurchase (or defect using) the service from the same supplier (Zeithaml et al. 1996). Certain behaviours signal that customers are forging bonds with a company. When customers praise the firm, express preference for the company over others, increase the volume of their purchases, or agreeably pay a price premium, they are indicating behaviourally that they are bonding with the company. Likewise, when customers perceive a lower service performance (quality), they are likely to exhibit behaviours signalling they are on the edge of leaving the company or spend less with the company (Zeithaml et al. 1996).

In this study, we present three indicators of behavioural intentions to identify the factors that may have greater impact on the customers' decision regarding their future relationship with their bank. These are (1) whether they would increase the frequency of using the services of their bank; and (2) whether they would recommend the services of their bank to a 
colleague (friend); and (3) whether they would switch to another bank for all their banking service needs if they had a choice. It is suggested that customers evaluate their service encounters along the quality dimensions identified in this study. Consequently, they may be influenced by these dimensions in their behavioural intentions. Theoretical and empirical studies suggest that service quality has an influence on future purchase intentions (Karatepe et al. 2005; Keillor et al. 2004; Zhou, 2004; Aldlaigan and Buttle, 2002; Bahia and Nantel, 2000; Cronin et al. 2000; Sweeney et al. 1997; Zeithaml et al. 1996; Parasuraman et al. 1994a; Richard and Allaway 1993). Therefore, we posit that when service quality perceptions are high, the customers' behavioural intentions are favourable, which strengthens the customer's relationship with the bank; otherwise the relationship is more likely to be weakened. Thus,

$\mathrm{H} 2 \mathrm{a}$ All bank service quality dimensions identified in this study will have a positive influence on the customers' future purchase intentions.

$\mathrm{H} 2 \mathrm{~b}$ All bank service quality dimensions identified in this study will have a positive influence on the customers' willingness to recommend the services of the bank to friends.

$\mathrm{H} 2 \mathrm{c}$ All bank service quality dimensions identified in this study will have a negative influence on the customers' willingness to switch to another bank.

\section{RESEARCH METHODOLOGY}

\section{Service Quality Variables, Questionnaire And Sample}

Establishing a service quality measurement instrument and the questionnaire to be designed for the purpose of this study is a multi-step process in itself. The first step in the development of a valid measurement model for the service construct is to define the domain of the quality concept. Bank service quality is, therefore, conceptualised in this study as the extent to which the service meets and/or exceeds the expectations of customers.

Although the dimensions of the SERVQUAL model mainly focus on human elements and tangible facets, in the present study we include other important dimensions such as core services, standardization of the service delivery (the non- human element) and the social responsibility of the organization. Hence, after an extensive review of literature, at this stage we identified 37 attributes that are important in measuring quality service.

As part of the development of a valid measure of quality attributes, Churchill (1979) suggests that an experience groups be involved in the attributes identification procedure. Consequently, exploratory interviews were conducted with experience groups with the aim of adopting those items which are relevant for the customers of the two banks in Eritrea. To this effect, we presented the 37 attributes to 10 employees (5 employees each) from the CBER and HCBE. The employees represent various groups ranging from an ordinary employee up to division managers, who possess a wealth of experience. In addition, the same attributes were also circulated to 10 local and expatriate customers ( 5 from each bank). An extensive focus group discussions and interviews were held with both groups (employees and customers) on the relevance of the attributes in the context of the Eritrean banks. As a result, the attributes increased from 37 to 44 items.

Based on the rigorous procedure that we have followed for the purpose of developing a valid measure, we believe that the above items sufficiently encompass the attributes on which customers of the two banks form their perceptions of bank service quality. This procedure has enabled us to identify the attributes that are to be incorporated in the final survey instrument. In addition, six items related to various measures such as overall quality, customers' behavioural intentions, customer satisfaction etc were included. One question was also elicited to assess the respondent's ability to evaluate his/ her bank? The survey, therefore, employed a total of 50 items plus a self-assessment question on respondents' suitability for the survey. A set of Likert type scales was used to measure pertinent constructs. Each quality attribute (customer expectations or customer perceptions) was answered using a seven-point scale, where $1=$ absolutely disagree and $7=$ absolutely agree. However, 6 of the 44 items were first eliminated altogether during factor analysis since they were related to the internal employees' situation in which it was not visible for customers to perceive it. Hence, only 38 items were considered. 
The survey instrument was administered through enumerators in the spring of 2009 to about 626 customers in different branches of the two banks in three major cities which resulted in 619 usable responses. We obtained 338 and 281 usable responses from customers in CBER and HCBE respectively.

Dependent variables: the dependent variables are: (1) 'overall service quality' perception which is operationalized using a seven-point scale, where $1=$ very poor and $7=$ excellent, and (2) 'customers' behavioural (future purchase) intentions' using the three indicators mentioned earlier.

Independent variables: the independent variables of the model are the quality dimensions identified through factor analysis of the quality attributes.

Control variables: four control variables, namely age, gender, education, and marital status of the respondents were used.

\section{RESULTS}

The 38 quality attributes were reduced to a manageable size of underlying factors (dimensions) that reflect the essence of these attributes through factor analyses. Factor analysis for the CBER variables resulted in four service quality dimensions, namely: 'courteous and responsive', 'reliability and service mindedness', 'service appearance', and 'service convenience'. The factor solutions are shown in Table 1. The table list the reliability of the factors as measured by Cronbach (alpha) coefficient (de Vaus 1996) and the variance accounted for by the factors. The minimum 0.7 alpha rule of thumb was obtained for all four factors (the lowest is 0.76). This shows that the factors have high internal consistency.

During the factor analysis process 14 quality attributes out of the 38 were eliminated because either they had weak (low) factor loadings or they loaded highly in more than one dimensions. The factor solution accounted for a variance of almost 60 percent.

As Table 2 shows the factor solution for the HCBE quality attributes accounted for a variance of 63.4 percent. None of the factors violated the minimum 0.70 alpha rule of thumb indicating the reliability of the variables.
Factor analysis on the HCBE variables resulted in five quality factors-'courteous and responsive', 'service mindedness', 'service appearance', 'accessibility and empathy', and 'service enhancement.' During the factor analysis procedure, ten quality attributes were eliminated because of low factor loadings. The remaining variables have factor loadings over the cut-off point of 0.50 except for two variables which have below 0.50 but above 0.46 loading.

An examination of the correlation matrix in Tables 3 and 4 indicate that the quality dimensions identified in this study are moderately correlated with overall service quality and satisfaction which are similar constructs. The model also showed moderate discriminant validity by correlating more with overall quality than with two of the measures of behavioural intentions (Recommend and Switch).

A regression analysis is employed to test the hypotheses posited. Two regression models are formulated to test the relationships implied by the hypotheses. The regression model for testing this hypothesis (Model 1) is expressed as:

$$
\begin{aligned}
& \text { OSQx }=\quad C+a 0 S Q F 1 p x+a 1 \text { SQF2px + a2 } \\
& \text { SQF3px }+\ldots
\end{aligned}
$$

Table 5 below presents the result of regression model for CBER. The table shows that the variables in the model explain a significant variance of overall service quality. The adjusted R-squared is rather high (0.44). In general, the quality dimensions identified for the CBER are found to be important determinants of overall service quality.

All of the dimensions significantly $(.000$ p-level) influence overall service quality in the hypothesized direction. Thus, the hypothesis with regard to overall service quality $(\mathrm{H} 1)$ is accepted. We also tested the model by including the biographical data (age, gender, education, and marital status) to see if they influenced the respondents' perception of their bank's service quality. The result was that all of these biographical variables have no influence.

Regarding HCBE the variables in the model explain a significant variance of overall service quality. Table 6 below shows that the adjusted $\mathrm{R}$-squared is rather high (0.40). Once more, the quality dimensions identified for the HCBE are 
found to be significant determinants of overall service quality.

For the HCBE also, all of the dimensions are found to be statistically significant predictors of overall service quality. Consequently, the hypothesized relationships for the HCBE with regard to overall service quality $(\mathrm{H} 1)$ is accepted. In the HCBE also all of the biographical variables are excluded from the model since they do not have any effect.

A regression model (Model 2), which is stated below is also designed to test $\mathrm{H} 2 \mathrm{~A}, \mathrm{H} 2 \mathrm{~B}$, and $\mathrm{H} 2 \mathrm{C}$. This model has customers' behavioral intentions as a dependent variable:

$$
\begin{aligned}
& B I N T_{p x}=C+a_{0} S Q F 1_{p x}+a_{1} S Q F 2_{p x}+a_{2} \\
& S Q F 3_{p x}+\ldots
\end{aligned}
$$

The result of regression model on customers' willingness to continue using the services of the bank, to recommend the bank to friends, and switch to another bank is presented in table 7 . The table shows that the model resulted in a significant prediction for the customers' future purchase intentions of CBER's services. The adjusted R-squared is rather high (0.42). In general, the quality dimensions identified for the CBER are found to be important determinants of clients' behavioural intentions when defined as customers' willingness to continue using the services of the incumbent bank.

Statistically, all of the dimensions significantly $(.000 \mathrm{p}$-level) influence customers' future purchase intentions in the hypothesized direction. Thus, hypothesis $(\mathrm{H} 2 \mathrm{~A})$ is accepted. This perhaps indicates that customers are relatively satisfied with CBER's current overall services. However, there is a possibility that customers want to increase the purchase of services from this bank because they do not perceive themselves as having other options. ${ }^{1}$

As far as customers' willingness to spread positive word-of-mouth about CBER to friends is concerned, the model did not result in significant prediction of the independent variable using the dimensions of service quality. The adjusted R-squared is extremely low. Generally, the quality dimensions identified in this study are not important determinants of customers' intentions

\footnotetext{
${ }^{1}$ The CBER and the HCBE are the only banks available to private customers.
}

to recommend the services of their banks to others.

Notwithstanding, the table shows that some of the variables in the model are associated with the independent variable but in a direction opposite to our hypothesis. Of all the quality dimensions, "courteous and responsive" and "service appearance" are found to be statistically significant negative determinants, whereas "reliability and service mindedness" and "service convenience" are statistically insignificant. It should be noted, however, that of the biographical variables, education was found to have a significant (0.01 p-level) positive influence. In conclusion, the quality dimensions identified for the CBER are not very significant determinants of this type of behavioural intention. Therefore, hypotheses H2B is rejected.

Furthermore, the model resulted in a moderately significant prediction for the customers' intention to switch to another bank for all their banking service needs if they had a choice (adj. $R$-squared of 0.20 ). Some of the variables in the model have a significant but unexpectedly positive impact on this type of behavioural intention. In this case, "courtesy" and "reliability and service mindedness" are found to have statistically significant impact. Conversely, "service appearance" and "service convenience" are statistically insignificant, although at 0.10 significance level, "service appearance" can be regarded as having impact.

Regarding HCBE, the result of regression model on customers' willingness to continue using the services of the bank, to recommend the bank to friends, and switch to another bank is presented in table 8. The regression model also resulted in a moderately significant prediction for customers' intention to increases using the services of the bank. The adjusted R-squared is on the high side. In general, the quality dimensions are found to be very important determinants of clients' behavioural intentions.

All of the dimensions influence clients' future purchase intentions in the hypothesized direction. Thus, the hypothesis with regard to future purchase intentions $(\mathrm{H} 2 \mathrm{~A})$ is accepted for the HCBE. Therefore, it seems plausible that customers are relatively satisfied with HCBE's current overall services. It should be noted, 
however, that age and gender were found to have significant $(0.01 \mathrm{p}$-level) negative influence on future use. This means that older and male respondents are less willing to increases using the services of the HCBE.

With regard to 'recommending the bank to friends', the adjusted $R^{2}$ is extremely low (0.03). In addition, with the exception of one, none of the variable in the model influences customers' intention to recommend the purchase of services from the bank. The exception is the bank's accessibility and empathy towards its customers' which was found to be statistically significant. However, the influence is on the negative direction. In general, therefore, the quality dimensions identified for the HCBE are not important determinants for clients' to recommend to others. Hence, our hypothesis on this behavioural intention ( $\mathrm{H} 2 \mathrm{~B})$ is rejected. Once more, of the biographical variables, education was found to have a significant $(0.01 \mathrm{p}$-level) positive influence on willingness to recommend the bank's service to others implying that more educated customers have relatively a positive attitude towards the HCBE.

Furthermore, the adjusted $R^{2}$ for the behavioural intention 'switch to another bank' is rather low (0.09). Nevertheless, the model seems to indicate that, to some extent, "service mindedness", being "courteous and responsive" to customers', and "service enhancement" have positive association with the customers' intention to switch to another bank for all their banking service needs if they had a choice. Here also, the result is contrary to our expectations. The implication is that the better the HCBE performs in these three quality dimensions the more willing are the customers to abandon the bank. Perhaps we may speculate that the HCBE also suffers from unfavourable perception of image (reputation). It is argued that a prolonged deterioration of service performance brings about gradual but long-lasting image deterioration (Lehtinen and Lehtinen 1991; Grónroos 1984). Nonetheless, we want to acknowledge that the question on this behavioural intention may have been misunderstood.

The dimensions "accessibility and empathy" and "service appearance" are not perceived as making any difference. In general, the quality dimensions in the HCBE have little predictive value in the opposite direction of the hypothesis. Therefore, hypothesis $\mathrm{H} 2 \mathrm{C}$ for the HCBE is rejected. All of the biographical variables failed to have any effect on the behavioural intention 'switch bank'.

\section{DISCUSSIONS AND CONCLUSION}

In this study, we have tried to identify quality dimensions that influence overall banking service quality in the CBER and HCBE. The service quality dimensions identified through factor analysis were analysed further to determine their influence on customers' perception of overall service quality and behavioural intentions. Customers were asked to assess the overall service quality of their banks in a single 7-point bi-polar scale. The dimensions of service quality were then regressed against this overall service quality score. Overall service quality was hypothesized to be positively influenced by all quality dimensions identified in this study.

It appears that customers' base their banks' overall quality assessment on the service quality dimensions identified in this study. As hypothesized, all quality dimensions positively influence overall service quality of both banks. However, there is still a significant portion of the variance of overall service quality which is not explained by the quality dimensions of this study.

In addition, behavioural intentions are operationalised as factors that may have greater impact on the customers' decision regarding their future relationship with CBER and HCBE. We hypothesized that the first two types of behavioural intentions (future use and recommend the services of the bank to friends) would be positively influenced by the service quality dimensions of both banks. The third unfavourable behavioural intention (switch to another bank) was expected to be negatively related to the quality dimensions. Our results of CBER indicated that the quality dimensions identified in this study have significant influence on the customers' intention to increase the frequency of using the services of the bank. On the other hand, some of the most important quality dimensions for customers' intention to recommend the services to a colleague are not significant, and even those who have mere significance are in the opposite direction. Hence, our hypothesis is notaccepted. It should, however, 
be noted that in the case of CBER education was found to have a positive influence on the intention to recommend to friends. This hints that more educated customers are more willing to recommend the banks service to others. As far as switching to another bank is concerned, some variables have significant influence, but contrary to the hypothesized direction. The implication of this is that the better the bank performs in these significant dimensions the less willing are the customers to continue using its services if they had a choice to shift to other banks. We found this to be a paradox. Although we do not know the reason of this contradiction, we may speculate that CBER has suffered a persistent image loss that a short-term performance in the quality dimensions identified would not be sufficient to convince customers to remain loyal. However, it is well possible that the respondents did not understand the way the question on the 'switch bank' variable was formulated. Nevertheless, it is comforting to observe that, relatively speaking, more educated respondents are less willing to switch bank as education was found to have a significant $(0.05 \mathrm{p}$-level) negative influence on clients desire to switch to other banks. Hypothesis $\mathrm{H} 2 \mathrm{C}$ is, thus, not supported for the CBER. Moreover, education was found to have a negative influence on the decision to switch to other banks if the customers had the chance to do so. That is, those who are more educated are less willing to switch to another bank.

Similar results have been obtained for the HCBE. That is, the quality dimensions identified in this study have significant influence on the customers' intention to increase the frequency of using the services of HCBE. Among others, age and gender were found to have negative influence on customers' intention to increase the use of their banking services. That is, male and older respondents are less willing to continue to use the services of their bank. Also some of the quality dimensions for customers' decision to recommend the services to a friend are not significant, and even those significant are in the opposite direction. However, here also the message could be that the customers would continue to buy services because they have extremely limited option from which they can buy the same type of services. Nevertheless, education was found to have a positive influence on customers' decision to recommend to others.
That is, those who are more educated are more willing to recommend to a friend. Furthermore, most of the quality dimensions do not have significant influence on customers' decision to switch to another bank and, like for the CBER, those that have mere significant are in the opposite direction.

Generally, customers do not consider the service quality dimensions identified in both banks to be important in their intention to recommend their services to friends. Similarly, most of the quality dimensions are not significant determinants of customers' intention to switch to other banks albeit having a minor influence. In conclusion, there may be considerations, other than the quality dimensions identified in this study on which customers base their decisions with regard to spreading positive word-of-mouth communication about the banks or switching to another bank.

\section{IMPLICATIONS OF THE STUDY}

There are significant theoretical implications that can be derived from this study. The main contribution of the present study is the formulation of a comprehensive framework for studying service quality in a banking sector in a developing-country context. To-date, many research on service quality in a banking sector in Africa in general, and in Eritrea in particular is scarce. Accordingly, this study attempts to start a data-base of research on service quality in the banking sectors on which more enriching studies are expected to be built. In comparison with similar service quality studies made in other countries, this study has come-up with new dimensions. Hence, the outcome may enrich our understanding of services marketing and the determinant variables in what customer perceive regarding quality service in developing countries.

The empirical study revealed mixed evidence in that, although customers' base their banks' overall quality assessment on the service quality dimensions identified in this study, they do not consider the service quality dimensions identified to be important in their intention to spread positive word-of-mouth about their bank's services to colleagues and they seem to be willing to switch to another bank even with a positive perception of service quality. Thus, there may be considerations other than the quality dimensions 
identified in this study on which customers base their future purchase which seeks further study.

In addition, this study gives a broad insight on the study of service quality in a banking sector, because it incorporates the wider view of employees and customers in identifying the attributes of service quality.

As with many other researches in service quality, this study has limitation and thus readers must be cautious in making generalisations. First, our study was conducted for two Eritrean banks engaged in the commercial and housing banking services. Thus, the findings may not be generalizable to other bank and financial institution in Eritrea, nor can they be to the banking sector in other countries.

Our study also has limitations arising from the research method and data analysis techniques. Factor analysis involves a certain degree of subjectivity in arriving at the best possible factor solutions. For example, some quality dimensions included variables which appear to be conceptually less related. As a result some factors were found to be difficult to name and interpret. That is basically the reason why we used two words to name some of the quality dimensions. We also felt that some of the questions in the questionnaire may not have been well understood by the respondents. Access to more recent literature was also another significant limitation.

Finally, two out of the four biographical variables are dummies and, thus, might be expected to be fairly less powerful models. Nevertheless, we were able to make some important conclusions from the results of these models.

\section{REFERENCES}

Aldlaigan, A.H. and F.A. Buttle (2002), SYSTRA-SQ: a new measure of bank service quality, International Journal of Service Industry Management, Vol. 13, No. 4, 362-381.

Babakus, E. and G. W. Boller (1992), An Empirical Assessment of the SERVQUAL Scale, Journal of Business Research, Vol. 24, 253-268.

Bahia, K. and J. Nantel (2000), A reliable and valid measurement for the perceived service quality of banks, International Journal of Bank Marketing, 18/2, 84-91.
Bolton, R. N. and Drew, J.H. (1991), A Multistage Model of Customers' Assessment of Service Quality and Value, Journal of Consumer Research, 17, 375-384.

Boshoff, C., et al. (1994), The Relative Influence of Service Quality in the Banking Industry, South African Journal of Business Management, (March), Vol. 25, No 1.

Buttle, F. (1996), SERVQUAL: review, critique, research agenda, European Journal of Marketing, Vol. 30, No. 1, 14.

Caruna, A., et al. (1998), Expectations about Management Consultancy Services: Testing the Assumptions of Equivalence Across, Australian and Singaporean Firms, Journal of Professional Services Marketing, Vol. 18 (1), 1-10.

Churchill, JR. G. A. (1979), A Paradigm for Developing Better Measures of Marketing Constructs, Journal of Marketing Research, Vol. XVI, 64-73.

Cronin, J. J. and S. A. Taylor (1992), Measuring Service Quality: A Re-examination and Extension, Journal of Marketing, Vol. 56, 55-68.

Cronin, J. J., et al. (2000), Assessing the Effects of Quality, Value, and Satisfaction on Consumer Behavioural Intentions in Service Environments, Journal of Retailing, Vol. 76 (2), 193-218.

Dassen, R. J. M., (1995), Audit Quality: An Empirical Study of the Attributes and Determinants of Audit Quality Perceptions, Ph.D. dissertation, University of Limburg.

de Vaus, D. A. (1996), Surveys in Social Research, Fourth Edition, UCL Press, London.

Grónroos, C. (1984), A Service Quality Model and its Marketing Implications, European Journal of Marketing, No. 4, 36-44.

Grónroos, C. (1990), Service Marketing and Management: Moments of Truth in Service Competition, D. C. Heath-Lexington Books, Lexington, MS.

Karatepe, O.M., et al. (2005), Measuring service quality of banks: Scale development and validation, Journal of Retailing and Consumer Services, 12, 373-383

Keillor, B. D., et al. (2004), A Study of the Service Encounter in Eight Countries, Journal of International Marketing, Vol. 12, No. 1, 9-35.

Lehtinen, U. and J. R. Lehtinen (1991), Two Approaches to Service Quality Dimensions, The Service Industries Journal, Vol. 11, No. 3, (July), 287303.

Mongos, N. C., et al. (1995), Research Note: Marketing Accounting Services, A Cross-Cultural Com 
parison, International Marketing Review, Vol. 12, No. 6, 68-81.

Nagata, H., et al. (2004), The dimensions that construct the evaluation of service quality in academic libraries, Performance Measurement \& Metrics, Vol. 5, No. 2, 53-65.

Nel, D., et al. (1997), The SERVQUAL Instrument: Reliability and Validity in South Africa, South African Journal of Business Management, Vol. 28, Issue $3,113$.

Parasuraman, A., et al. (1991a), Perceived Service Quality as a customer-based Performance Measure; An Empirical Examination of Organisational Barriers Using an Extended Service Quality Model, Human Resource Management, Vol. 30, No. 3, (Autumn), 335-64.

Parasuraman, A. et al. (1985), A Conceptual Model of Service Quality: Implications for Future Study, Journal of Marketing, 49 (Fall), 41-50.

Parasuraman, A. et al. (1988), SERVQUAL: A Multiple-Item Scale for Measuring Consumer Perceptions of Service Quality, Journal of Retailing, Vol. 64, No1, (Spring), 12-40.

Parasuraman, A. et al. (1994a), Reassessment of Expectations as a comparison Standard in Measuring Service Quality: Implications for Further Research, Journal of Marketing, Vol. 58, (January), 111-124.

Reeves, C. A. and D. A. Bednar (1994), Defining Quality: Alternatives and Implications, Academy of Management Review, Vol. 19, No. 3, 419-445.

Richard, M. D. and A. W. Allaway (1993), Service Quality Attributes and Choice Behaviour, Journal of

Service Marketing, Vol. 7, No. 1, 59-68.

Sadchev, S. B. and H. V. Verma (2002), Customers Expectations and Service Quality Dimensions Consistency, Journal of Management Research, Vol. 2, No. 1, (April), 43-52.

Sweeney, J. C. et al. (1997), Retail Service Quality and Perceived Value, Journal of retailing and Consumer Services, Vol. 4, No. 1, 39-48.

Teas, R. K. (1993), Expectations, Performance Evaluation, and Consumers Perceptions of Quality, Journal of Marketing, Vol. 57, (October), 18-34.

Tsegai, A. (1999), Challenges and tasks of financial intermediaries in Eritrea, paper presented at a National workshop on Development of Finance, Banking and Insurance, Teraemni, Eritrea.

Urdang, B. S. and R. M. Howey (2001), Assessing Damages for Non-performance of a travel Professional-a Suggested Use of "SERVQUAL", Tour- ism Management, 22, 533-538.

Woo, K. and C. T. Ennew (2005), Measuring Business-to-Business Professional Service Quality and its Consequences, Journal of Business Research, $58,1178-1185$.

Zeithaml, V. A. et al. (1988), A Communication and Control Processes in the Delivery of Service Quality, Journal of Marketing, 52, 35-48.

Zeithaml, V. A. et al. (1996), The behavioural Consequences of Service Quality, Journal of Marketing, Vol. 60 (April), 31-46.

Zeithaml, V. A. et al. (1990), Delivering Quality Service, New York Free Press.

Zhou, L. (2004), A dimension specific analysis of performance only measurement of service quality and satisfaction in China's retail banking, Journal of Services Marketing, Vol. 18, No. 7, 534-546. 
Table 1. Factor solution for CBER

\begin{tabular}{|c|c|c|}
\hline $\begin{array}{l}\text { Dimensions (Cronbach's Alfa) } \\
\text { (Cumulative variance) }\end{array}$ & Variables $^{\mathrm{a}}$ & Factor Loadings \\
\hline \multirow[t]{3}{*}{ Courteous and responsive } & Neat professional appearance & .737 \\
\hline & Pleasing and courteous employees & .713 \\
\hline & Employees with proper behaviour & .673 \\
\hline \multirow[t]{4}{*}{$(16.3)$} & Effective customer grievance procedures & .661 \\
\hline & A sense of public responsibility & .590 \\
\hline & Services right the first time. & .521 \\
\hline & $\begin{array}{l}\text { Caring and individual attention to cus- } \\
\text { tomers }\end{array}$ & .516 \\
\hline \multirow{8}{*}{$\begin{array}{l}\text { reliability and service mind- } \\
\text { edness }\end{array}$} & Fail-safe procedures and processes & .714 \\
\hline & $\begin{array}{l}\text { Good service at a reasonable cost, but } \\
\text { not at the expense of quality }\end{array}$ & .635 \\
\hline & Meet customers request quickly & .608 \\
\hline & $\begin{array}{l}\text { Continuously appraise and upgrade their } \\
\text { services }\end{array}$ & .599 \\
\hline & $\begin{array}{l}\text { Make customers realize their unexpect- } \\
\text { ed needs by giving more than what they } \\
\text { expect. }\end{array}$ & .568 \\
\hline & Adequate and necessary facility & .548 \\
\hline & $\begin{array}{l}\text { Highly simplified and structured delivery } \\
\text { process with minimum delivery times }\end{array}$ & .548 \\
\hline & $\begin{array}{l}\text { Leading corporate citizen and promote } \\
\text { ethical conduct }\end{array}$ & .545 \\
\hline \multirow[t]{5}{*}{ Service appearance } & Favourable ambient conditions & .808 \\
\hline & $\begin{array}{l}\text { Physical layout comfortable for custom- } \\
\text { ers to interact with employees }\end{array}$ & .720 \\
\hline & $\begin{array}{l}\text { House keeping as a priority and of the } \\
\text { highest order }\end{array}$ & .668 \\
\hline & $\begin{array}{l}\text { Make customers safe and secure in their } \\
\text { transactions }\end{array}$ & .547 \\
\hline & Wide range of financial services & .515 \\
\hline \multirow[t]{4}{*}{ Service convenience } & Visually appealing signs & .812 \\
\hline & $\begin{array}{l}\text { Convenient branch locations in most } \\
\text { places }\end{array}$ & .752 \\
\hline & $\begin{array}{l}\text { Enhanced technology capability to serve } \\
\text { customers more effectively. }\end{array}$ & .676 \\
\hline & $\begin{array}{l}\text { Apprises customers of nature and sched- } \\
\text { ule of services available }\end{array}$ & .622 \\
\hline
\end{tabular}

${ }^{a}$ The statement of the variables are abbreviated in order to make them fit to the table. 
Table 2. Factor solution for HCBE

\begin{tabular}{|c|c|c|}
\hline $\begin{array}{l}\text { Dimensions (Cronbach's Alfa) (Cumu- } \\
\text { lative variance) }\end{array}$ & Variables & Factor Loadings \\
\hline \multirow{8}{*}{$\begin{array}{l}\text { Accessibility and empathy } \\
(0.91) \\
(14.814)\end{array}$} & $\begin{array}{l}\text { Highly standardized and simplified delivery pro- } \\
\text { cess without excessive bureaucracy }\end{array}$ & .723 \\
\hline & $\begin{array}{l}\text { Highly simplified and structured delivery process } \\
\text { with minimum delivery times }\end{array}$ & .714 \\
\hline & Caring and individual attention to customers & .672 \\
\hline & Meet customers request quickly & .624 \\
\hline & Convenient operating hours and days & .615 \\
\hline & Knowledge and competence of employees & .505 \\
\hline & Services right the first time. & .501 \\
\hline & $\begin{array}{l}\text { Willingness to help customers and ready to re- } \\
\text { spond to customers request }\end{array}$ & .464 \\
\hline \multirow{5}{*}{$\begin{array}{l}\text { Service appearance } \\
(0.86)\end{array}$} & $\begin{array}{l}\text { Physical layout comfortable for customers to inter- } \\
\text { act with employees }\end{array}$ & .733 \\
\hline & $\begin{array}{l}\text { House keeping as a priority and of the highest or- } \\
\text { der }\end{array}$ & .718 \\
\hline & Favourable ambient conditions & .666 \\
\hline & Adequate and necessary facility & .583 \\
\hline & $\begin{array}{l}\text { Enhanced technology capability to serve custom- } \\
\text { ers more effectively. }\end{array}$ & .562 \\
\hline \multirow[t]{6}{*}{ Courteous and responsive } & Pleasing and courteous employees & .828 \\
\hline & Neat professional appearance & .604 \\
\hline & $\begin{array}{l}\text { Effective employees skills and ability whenever a } \\
\text { critical incident takes place }\end{array}$ & .569 \\
\hline & Employees with proper behaviour & .559 \\
\hline & Never too busy to respond requests & .530 \\
\hline & $\begin{array}{l}\text { Employees who understand the needs of their } \\
\text { customers }\end{array}$ & .509 \\
\hline \multirow[t]{5}{*}{ Service mindedness } & Visually appealing signs & .726 \\
\hline & $\begin{array}{l}\text { Make customers realize their unexpected needs } \\
\text { by giving more than what they expect. }\end{array}$ & .640 \\
\hline & Continuously appraise and upgrade their services & .589 \\
\hline & Equal treatment of customers & .540 \\
\hline & Most services found in branches & .488 \\
\hline \multirow[t]{4}{*}{ Service enhancement } & Fail-safe procedures and processes & .709 \\
\hline & A sense of public responsibility & .629 \\
\hline & Services at the promised schedule & .552 \\
\hline & Availability of ATM & .506 \\
\hline
\end{tabular}


Fitsum Ghebregiorgis and Asmerom Atewebrhan, IJIBM, 2017; 1:5

Table 3. Correlation coefficients for testing convergent and discriminant validity: CBER

\begin{tabular}{|c|c|c|c|c|c|c|c|c|c|c|}
\hline & & 1 & 2 & 3 & 4 & 5 & 6 & 7 & 8 & 9 \\
\hline 1 & Courtesy & 1.000 & & & & & & & & \\
\hline 2 & $\begin{array}{l}\text { Reliability } \\
\text { and service } \\
\text { mindedness }\end{array}$ & 0.04 & 1.000 & & & & & & & \\
\hline 3 & $\begin{array}{l}\text { Service ap- } \\
\text { pearance }\end{array}$ & 0.03 & 0.00 & 1.000 & & & & & & \\
\hline 4 & $\begin{array}{l}\text { Service con- } \\
\text { venience }\end{array}$ & .024 & 0.02 & -0.03 & 1.000 & & & & & \\
\hline 5 & $\begin{array}{l}\text { O ve r a II } \\
\text { quality }\end{array}$ & $0.36^{* *}$ & $0.34^{* *}$ & $0.39 * *$ & $0.21^{* *}$ & 1.000 & & & & \\
\hline 6 & Satisfaction & $0.44 * *$ & $0.32^{* *}$ & $0.31 * *$ & $0.26 * *$ & $0.67 * *$ & 1.000 & & & \\
\hline 7 & Future use & $0.36^{* *}$ & $0.27^{* *}$ & $0.42 * *$ & $0.26^{* *}$ & $0.68^{* *}$ & $0.64^{* *}$ & 1.000 & & \\
\hline 8 & $\begin{array}{l}\text { R e c o m - } \\
\text { mend }\end{array}$ & -0.10 & 0.02 & $-0.19 * *$ & -.02 & $-0.16^{* *}$ & $-0.15^{* *}$ & $-0.21 * *$ & 1.000 & \\
\hline 9 & Switch & $0.30^{* *}$ & $0.35 * *$ & 0.09 & 0.01 & $0.37 *$ & $0.39 * *$ & $0.35 * *$ & -0.07 & 1.000 \\
\hline
\end{tabular}

** Correlation is significant at the 0.01 level (2-tailed). * Correlation is significant at the 0.05 level (2-tailed)

Table 4. Correlation coefficients for testing convergent and discriminant validity: HCBE

\begin{tabular}{|c|c|c|c|c|c|c|c|c|c|c|c|}
\hline & & 1 & 2 & 3 & 4 & 5 & 6 & 7 & 8 & 9 & 10 \\
\hline 1 & $\begin{array}{l}\text { Accessi- } \\
\text { bility and } \\
\text { empathy }\end{array}$ & 1.000 & & & & & & & & & \\
\hline 2 & $\begin{array}{l}\text { Service ap- } \\
\text { pearance }\end{array}$ & -0.09 & 1.000 & & & & & & & & \\
\hline 3 & $\begin{array}{l}\text { Interactive } \\
\text { quality }\end{array}$ & 0.08 & 0.09 & 1.000 & & & & & & & \\
\hline 4 & $\begin{array}{l}\text { Service } \\
\text { Minded- } \\
\text { ness }\end{array}$ & -0.01 & 0.11 & 0.06 & 1.000 & & & & & & \\
\hline 5 & $\begin{array}{l}\text { Service } \\
\text { enhance- } \\
\text { ment }\end{array}$ & -0.04 & 0.08 & 0.10 & 0.07 & 1.000 & & & & & \\
\hline 6 & $\begin{array}{l}\text { Over r II } \\
\text { quality }\end{array}$ & $0.29 * *$ & $0.20^{* *}$ & $0.32^{* *}$ & $0.38^{* *}$ & $0.33^{* *}$ & 1.000 & & & & \\
\hline 7 & $\begin{array}{l}\text { Satisfac- } \\
\text { tion }\end{array}$ & $0.29^{* *}$ & $0.16^{* *}$ & $0.32^{* *}$ & $0.38^{* *}$ & $0.30^{* *}$ & $0.67^{* *}$ & 1.000 & & & \\
\hline 8 & Future use & $0.26^{* *}$ & $0.14^{*}$ & $0.35^{* *}$ & $0.35^{* *}$ & $0.22^{* *}$ & $0.58^{* *}$ & $0.60^{* *}$ & 1.000 & & \\
\hline 9 & $\begin{array}{l}\mathrm{R} \text { e c o m - } \\
\text { mend }\end{array}$ & $-0.13^{*}$ & -0.06 & 0.05 & 0.12 & -0.05 & 0.00 & 0.03 & 0.09 & 1.000 & \\
\hline 10 & Switch & 0.09 & 0.07 & $0.20^{* *}$ & $0.17^{* *}$ & $0.28^{* *}$ & $0.33^{* *}$ & $0.35^{* *}$ & $0.34^{* *}$ & -0.08 & 1.000 \\
\hline
\end{tabular}

** Correlation is significant at the 0.01 level (2-tailed). * Correlation is significant at the 0.05 level (2-tailed). 
Fitsum Ghebregiorgis and Asmerom Atewebrhan, IJIBM, 2017; 1:5

Table 5. Determinants of overall service quality for the CBER

\begin{tabular}{|l|l|l|l|}
\hline $\begin{array}{l}\text { Model } 1 \text { Independent vari- } \\
\text { ables }\end{array}$ & Std error & $\beta$ & Sig. \\
\hline (Constant) & .052 & & .000 \\
\hline Courteous and responsive & .051 & .356 & .000 \\
\hline $\begin{array}{l}\text { Reliability and service } \\
\text { mindedness }\end{array}$ & .051 & .363 & .000 \\
\hline Service appearance & .051 & .387 & .000 \\
\hline Service convenience & .052 & .196 & .000 \\
\hline Observations 338 & & \\
\hline F-value 67.717 & & \\
\hline Adj. R-squared 0.443 & & \\
\hline
\end{tabular}

Table 6. Determinants of overall service quality for the HCBE

\begin{tabular}{|l|l|l|l|}
\hline $\begin{array}{l}\text { Model } 1 \text { Independent vari- } \\
\text { ables }\end{array}$ & Std error & $\beta$ & Sig. \\
\hline (Constant) & .055 & & .000 \\
\hline Accessibility and empathy & .055 & .310 & .000 \\
\hline Service appearance & .055 & .173 & .000 \\
\hline Courteous and responsive & .055 & .265 & .000 \\
\hline Service Mindedness & .055 & .371 & .000 \\
\hline Service enhancement & .055 & .281 & .000 \\
\hline Observations 281 & & \\
\hline F-value 38.675 & & \\
\hline Adj. R-squared 0.402 & & \\
\hline
\end{tabular}

Table 7. Determinants of behavioural intentions for the CBER

\begin{tabular}{|c|c|c|c|c|c|c|c|c|c|}
\hline \multirow{2}{*}{$\begin{array}{ll}\begin{array}{l}\text { Model } 2 \\
\text { pendent }\end{array} & \text { Inde- } \\
\text { ables } & \\
\end{array}$} & \multicolumn{3}{|l|}{ Future } & \multicolumn{3}{|c|}{ Recommend } & \multicolumn{3}{|l|}{ Switch } \\
\hline & Std error & $\beta$ & Sig & Std error & $\beta$ & Sig & Std error & $\beta$ & Sig \\
\hline (Constant) & .060 & & .000 & .093 & & .000 & .099 & & .000 \\
\hline $\begin{array}{l}\text { Courteous and } \\
\text { responsive }\end{array}$ & .059 & .312 & .000 & .091 & -.112 & .037 & .097 & .266 & .000 \\
\hline $\begin{array}{l}\text { Reliability and } \\
\text { service minded- } \\
\text { ness }\end{array}$ & .059 & .274 & .000 & .092 & .023 & .664 & .097 & .364 & .000 \\
\hline $\begin{array}{l}\text { Service appear- } \\
\text { ance }\end{array}$ & .059 & .437 & .000 & .092 & -.201 & .000 & .098 & .093 & .058 \\
\hline $\begin{array}{l}\text { Service conve- } \\
\text { nience }\end{array}$ & .059 & .248 & .000 & .092 & -.033 & .539 & .098 & .019 & .694 \\
\hline $\begin{array}{l}\text { Observations } \\
\text { F-value }\end{array}$ & \multicolumn{3}{|l|}{338} & \multicolumn{3}{|l|}{338} & \multicolumn{3}{|l|}{338} \\
\hline Adj. R-squared & $\begin{array}{l}62.076 \\
0.421\end{array}$ & & & $\begin{array}{l}4.748 \\
0.043\end{array}$ & & & $\begin{array}{l}22.411 \\
0.204\end{array}$ & & \\
\hline
\end{tabular}


Fitsum Ghebregiorgis and Asmerom Atewebrhan, IJIBM, 2017; 1:5

Table 8. Determinants of behavioural intentions for the HCBE

\begin{tabular}{|c|c|c|c|c|c|c|c|c|c|}
\hline \multirow{2}{*}{$\begin{array}{lr}\text { Model } 2 & \text { Inde- } \\
\text { pendent } & \text { vari- } \\
\text { ables } & \end{array}$} & \multicolumn{3}{|l|}{ Future } & \multicolumn{3}{|c|}{ Recommend } & \multicolumn{3}{|l|}{ Switch } \\
\hline & Std error & $\beta$ & Sig & Std error & $\beta$ & Sig & Std error & $\beta$ & Sig \\
\hline (Constant) & .063 & & .000 & .112 & & .000 & .111 & & .000 \\
\hline $\begin{array}{l}\text { Accessibility and } \\
\text { empathy }\end{array}$ & .063 & .255 & .000 & .112 & -.138 & .020 & .111 & .077 & .179 \\
\hline $\begin{array}{l}\text { Service appear- } \\
\text { ance }\end{array}$ & .063 & .110 & .026 & .112 & -.076 & .199 & .111 & .011 & .850 \\
\hline $\begin{array}{l}\text { Courteous and } \\
\text { responsive }\end{array}$ & .063 & .314 & .000 & .112 & .080 & .179 & .111 & .145 & .012 \\
\hline $\begin{array}{l}\text { Service Minded- } \\
\text { ness }\end{array}$ & .063 & .379 & .000 & .112 & .106 & .073 & .111 & .141 & .014 \\
\hline $\begin{array}{l}\text { Service enhance- } \\
\text { ment }\end{array}$ & .063 & .147 & .003 & .112 & -.045 & .445 & .111 & .254 & .000 \\
\hline $\begin{array}{l}\text { Observations } \\
\text { F-value } \\
\text { Adj. R-squared }\end{array}$ & \multicolumn{3}{|l|}{281} & \multicolumn{3}{|l|}{281} & \multicolumn{3}{|l|}{281} \\
\hline & 0.328 & & & 0.027 & & & 0.094 & & \\
\hline
\end{tabular}

